medRxiv preprint doi: https://doi.org/10.1101/2021.01.10.21249537; this version posted January 11,2021 . The copyright holder for this preprint (which was not certified by peer review) is the author/funder, who has granted medRxiv a license to display the preprint in perpetuity.

It is made available under a CC-BY-NC 4.0 International license .

\title{
Excess mortality during the 1918-20 influenza pandemic in Czechia
}

\author{
Hampton Gray Gaddy ${ }^{1}$ \\ Updated 10 January 2021
}

\begin{abstract}
This research letter provides a replicable estimate of the mortality that the 1918-20 influenza pandemic caused in Czechia. A monthly all-cause excess mortality model identified clear periods of pandemic mortality in September 1918 through May 1919 and January 1920 through May 1920. The total excess mortality in those months implies a pandemic death toll of 71,967 and a national death rate of $0.75 \%$.
\end{abstract}

Introduction

Given its near-global scope and short duration, the influenza pandemic that began in 1918 was one of the highest mortality events in modern human history. Since the resumption of interest in the pandemic in the 1990s, global, national, and local literatures about the pandemic have steadily grown (1-4). This research letter estimates the mortality that the pandemic caused in the Central European country of Czechia.

In general, the pandemic caused mortality over several waves. In parts of the world with reliable data, most deaths occurred in two successive waves during the last quarter of 1918 and first quarter of 1919. For 14 national European populations, roughly $0.34 \%$ (Denmark) to $2.23 \%$ (Portugal) of each population died in those two waves (4). Defining the temporal boundaries of the pandemic is difficult (5-7), but a clinically similar wave in early 1920 (4) and a clinically less severe, 'herald' wave earlier on in 1918 are also well documented (8).

Cause of death attribution in the face of a poorly understood threat is often difficult. As such, those outlying waves were substantiated and the mortality of the main waves themselves is often estimated using excess mortality models $(4,5,7,9)$. These models assume an all-cause or cause-specific baseline mortality rate for a population and apply it as a counterfactual to the observed mortality data from the pandemic period. The difference between the observed and counterfactual mortality is taken as the pandemic death toll, subject to caveats about the validity of the counterfactual (10) and how proximate and ultimate causes of death are conceptualized (11-14).

\section{Methods}

The Czech Statistical Office reports monthly all-cause death counts for the Czech lands - the territory that comprises the Czech parts of Austria-Hungary, the Czech part of Czechoslovakia, and the modern state of Czechia. The monthly counts from January 1914 to December $1923(15,16)$ were fitted to a cyclical Serfling regression model that estimated temporal and seasonal fluctuation in baseline mortality over the study period $(9,17)$. The months of October and November 1918 and February and March 1920 were removed from the training set, as these were the months with the most abnormal mortality by far. For all periods historically associated with the pandemic, months of all-cause deaths that were significantly in excess of the baseline regression fit were interpreted as periods of pandemic mortality. My results are fully replicable with the provided death count data and R code (18).

\footnotetext{
NOTE: This preprint reports new research that has not been certified by peer review and should not be used to guide clinical practice.

${ }^{1}$ Institute of Human Sciences, University of Oxford; hampton.gaddy@magd.ox.ac.uk
} 
medRxiv preprint doi: https://doi.org/10.1101/2021.01.10.21249537; this version posted January $11,2021$. The copyright holder for this preprint (which was not certified by peer review) is the author/funder, who has granted medRxiv a license to display the preprint in It is made available under a CC-BY-NC 4.0 International license.

Figure 1

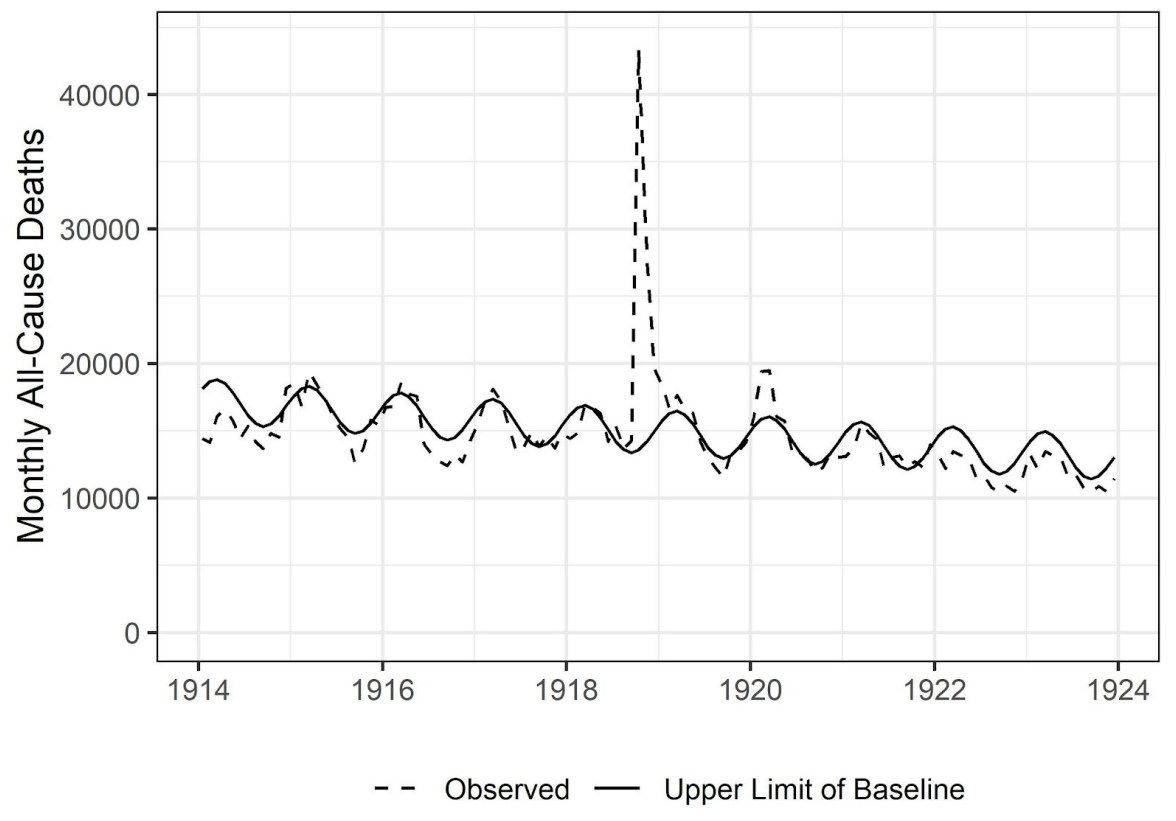

Results

Figure 1 displays the observed monthly death totals in Czechia between 1914 and 1923. It also shows the $99.9 \%$ confidence interval of the fitted cyclical regression model as an upper limit on baseline mortality. There is clear excess mortality in the periods of September 1918 through May 1919 and January 1920 through May 1920. The total difference between the observed and mean baseline mortality in those months is 71,967 deaths. Out of an estimated 1918 population of 9,624,230 in the Czech lands (15), this implies a pandemic death rate of $0.75 \%$.

The model suggests that there were 51,763 deaths $(72 \%$ of the total) between September and December $1918,8,526$ deaths (12\% of the total) between January and May 1919 , and 11,678 deaths ( $16 \%$ of the total) between January and May 1920 . There is less clear evidence for pandemic mortality before September 1918. Observed mortality in May and July 1918 did clearly exceed the confidence interval on the baseline mortality regression. Those months saw 950 and 1,719 excess deaths relative to the mean baseline estimate. The existence of herald mortality in May 1918 in Central Europe is not generally supported by the literature, but the much more reasonable inclusion of excess mortality from July 1918 increases the total pandemic death toll to 73,686 . This yields an estimated total pandemic death rate of $0.77 \%$.

\section{Discussion}

In terms of mortality, Czechia had a seemingly similar experience of the 1918-20 pandemic to other states in Western and Central Europe. For the waves at the end and beginning of 1918 and 1919, respectively, I calculate an excess death toll of 60,289 and an excess death rate of $0.63 \%$. This is similar to the monthly all-cause excess death rates of the Netherlands $(0.62 \%)$, Germany $(0.66 \%)$, France $(0.73 \%)$, and Switzerland $(0.77 \%)$ in those waves (4).

To my knowledge, this report is the first formal mortality study of the 1918-20 pandemic in Czechia, but it is preceded by a significant dissertation published in 2017 (19). As part of a historical overview of the outbreak in Czechia, it performed five rough mortality 
medRxiv preprint doi: https://doi.org/10.1101/2021.01.10.21249537; this version posted January $11,2021$. The copyright holder for this preprint (which was not certified by peer review) is the author/funder, who has granted medRxiv a license to display the preprint in perpetuity.

It is made available under a CC-BY-NC 4.0 International license .

calculations that placed the national death toll at between 44,000 and 77,000 . My estimate suggests that the true death toll fell on the higher end of that range.

This analysis has several limitations. Monthly death counts are assumed to be correct, and in particular, it is assumed that death registration did not vary non-linearly over the course of the study period. Death registration could have been relatively incomplete in the autumn of 1918 , in the face of the contemporary pandemic and political regime changes. If so, this would suggest a higher death toll than the one I report. There is also a discontinuity in the source of the monthly death count data between 1918 and $1919(15,16)$, but this seems to have no effect on the baseline trend (Figure 1). The estimation of a pandemic death rate assumes the accuracy of the national population count used. The population count used does not include military forces (19), and it is assumed that monthly death counts did not include them either. An estimated 5,000 to 10,000 additional pandemic deaths are estimated for the military, out of an unknown at-risk population (19). The standard assumption about the validity of excess mortality counterfactuals also applies.

However, this estimate was conducted in a similar manner to most other European mortality estimates for the 1918-20 pandemic. It strengthens and broadens the growing consensus on the mortality that Europe experienced in that pandemic.

\section{References}

1. Killingray D, Phillips H, eds. The Spanish Influenza Pandemic of 1918-1919: New Perspectives. London: Routledge; 2003.

2. Porras-Gallo M-I, Davis RA, eds. The Spanish Influenza Pandemic of 1918-1919: Perspectives from the Iberian Peninsula and the Americas. Rochester, NY: University of Rochester Press; 2014.

3. Killingray D. A New 'Imperial Disease': The Influenza Pandemic of 1918-9 and its Impact on the British Empire. Caribb Q. 2003;49(4):30-49.

4. Ansart S, Pelat C, Boelle P-Y, et al. Mortality burden of the 1918-1919 influenza pandemic in Europe. Influenza Other Respir Viruses. 2009;3(3):99-106.

5. Saglanmak N, Andreasen V, Simonsen L, et al. Gradual changes in the age distribution of excess deaths in the years following the 1918 influenza pandemic in Copenhagen: Using epidemiological evidence to detect antigenic drift. Vaccine. 2011;29(suppl 2):B42-B48.

6. Oxford JS. The so-called Great Spanish Influenza Pandemic of 1918 may have originated in France in 1916. Phil Trans R Soc Lond B. 2001;356(1416):1857-1859.

7. Chowell G, Simonsen L, Flores J, et al. Death Patterns during the 1918 Influenza Pandemic in Chile. Emerg Infect Dis. 2014;20(11):1803-1811.

8. Simonsen L, Chowell G, Andreasen V, et al. A review of the 1918 herald pandemic wave: importance for contemporary pandemic response strategies. Ann Epidemiol. 2018;28(5):281-288.

9. Serfling RE. Methods for current statistical analysis of excess pneumonia-influenza deaths. Public Health Rep. 1963;78(6):494-506.

10. Andreasen $V$, Simonsen $L$. The perils of using annual all-cause mortality data to estimate pandemic influenza burden. Vaccine. 2011;29(suppl 2):B49-B55.

11. Almond D. Is the 1918 Influenza Pandemic Over? Long-Term Effects of In Utero Influenza Exposure in the Post-1940 U.S. Population. J Polit Econ. 2006;114(4):672-712.

12. Noymer A. The 1918 influenza pandemic hastened the decline of tuberculosis in the United States: An age, period, cohort analysis. Vaccine. 2011;29(suppl 2):B38-B41. 
medRxiv preprint doi: https://doi.org/10.1101/2021.01.10.21249537; this version posted January $11,2021$. The copyright holder for this preprint (which was not certified by peer review) is the author/funder, who has granted medRxiv a license to display the preprint in It is made available under a CC-BY-NC 4.0 International license

13. Henry J, Smeyne RJ, Jang $\mathrm{H}$, et al. Parkinsonism and neurological manifestations of influenza throughout the 20th and 21st centuries. Parkinsonism Relat Disord. 2010;16(9):566-571.

14. Chandra S, Christensen J, Mamelund S-E, et al. Short-Term Birth Sequelae of the 1918-1920 Influenza Pandemic in the United States: State-Level Analysis. Am J Epidemiol. 2018;187(12):2585-2595.

15. Český statistický úřad. Přirozená měna obyvatelstva v zemích Koruny české v letech 1. světové války - 1914 - 1918.

https://www.czso.cz/csu/czso/prirozena-mena-obyvatelstva-v-zemich-koruny-ceske-v -letech-1-svetove-valky-1914-az-1918-n-y1naizbqp2. Published May 31, 2005. Accessed January 10, 2021.

16. Český statistický úřad. Demografické ročenky 1919 - 1923. https://www.czso.cz/csu/czso/casova_rada_demografie_1929_1919. Published March 16, 2018. Accessed January 10, 2021.

17. McConeghy KW, van Aalst R, Zullo A, et al. flumodelr: An R Package for Estimating Attributable Influenza Morbidity and Mortality. Version 0.1.0.9999 [software]. Updated May 20, 2019. Accessed January 9, 2021. https://kmcconeghy.github.io/flumodelr

18. R Core Team. R: A language and environment for statistical computing. Version 4.0.3 [software]. Vienna: R Foundation for Statistical Computing. Updated October 10, 2020. https://www.R-project.org/

19. Salfellner H. Pandemie španělské chřipky 1918/19 se zvláštním zřetelem na České země a středoevropské poměry [dissertation]. Prague: Charles University; 2017. https://is.cuni.cz/webapps/zzp/detail/147785/ 